\title{
A mountain of millipedes II: The genus Aquattuor Frederiksen, 2013 - five new species from the Udzungwa Mountains and one from Mt. Kilimanjaro, Tanzania (Diplopoda, Spirostreptida, Odontopygidae)
}

\author{
Henrik ENGHOFF ${ }^{1, *} \&$ Sara B. FREDERIKSEN ${ }^{1,2}$ \\ ${ }^{1}$ Zoological Museum, Natural History Museum of Denmark, University of Copenhagen, \\ Universitetsparken 15, DK-2100, Copenhagen Ø, Denmark \\ ${ }^{2}$ Department of Ecology, Animal Ecology, University of Marburg, Karl-von-Frisch-Straße 8, \\ D-35032 Marburg, Germany \\ *Corresponding author: henghoff@snm.ku.dk \\ ${ }^{2}$ Email: sara.frederiksen@snm.ku.dk \\ *urn:1sid:zoobank.org:author:FB09A817-000D-43C3-BCC4-2BC1E5373635 \\ ${ }^{2}$ urn:1sid:zoobank.org:author:6DE62DD5-0055-424A-A136-0EF290AF5AFD
}

\begin{abstract}
The genus Aquattuor Frederiksen, 2013 is revised. A. denticulatus Frederiksen, 2013 (type species) from the East Usambara Mts, Tanzania, is redescribed, and six new species are described: A. claudiahempae sp. nov. from Mt. Kilimanjaro, Tanzania, and five species from the Udzungwa Mts, Tanzania: A. longipala Enghoff sp. nov., A. major Enghoff sp. nov., A. stereosathe Enghoff sp. nov., A. submajor Enghoff sp. nov., and A. udzungwensis Enghoff sp. nov.
\end{abstract}

Keywords. Eastern Arc, Kilimanjaro, taxonomy, new species.

Enghoff H. \& Frederiksen S.B. 2015. A mountain of millipedes II: The genus Aquattuor Frederiksen, 2013 - five new species from the Udzungwa Mountains and one from Mt. Kilimanjaro, Tanzania (Diplopoda, Spirostreptida, Odontopygidae). European Journal of Taxonomy 150: 1-25. http://dx.doi.org/10.5852/ejt.2015.150

\section{Introduction}

This is the second in a series of articles about the millipedes, especially the family Odontopygidae, of the Udzungwa Mountains, Tanzania. For general information on the Odontopygidae and the Udzungwa Mountains, see the first paper in the series (Enghoff 2014). The present article, although not numbered as such, also forms a sequel to our previous papers on the odontopygids of East Africa (Frederiksen 2013a, 2013b; Frederiksen \& Enghoff 2012, 2015).

The genus Aquattuor was described by Frederiksen (2013b) for a relatively small odontopygid from the East Usambara Mountains, Tanzania. The genus, which has remained monotypic until now, is characterized by a slender, whiplike gonopodal solenomere and a simple telomere, combined with a unique structure of the metazonital limbus which consists of large, rectangular, easily detached flaps. 
Collecting activities in the Udzungwa Mountains by the NGO Frontier Tanzania and by staff and students from the University of Copenhagen ( $c f$. Enghoff 2014) have resulted in a considerable amount of material containing several new species of Aquattuor. At the same time, collections made in the framework of The KiLi Project (https://www.kilimanjaro.biozentrum.uni-wuerzburg.de/), sponsored by the German Research Foundation (cf. Frederiksen \& Enghoff 2015), have procured several samples of still another new species.

In the present article we describe six new species of Aquattuor, re-describe the type species, A. denticulatus Frederiksen, 2013, and provide an updated definition of the genus as well as a key to its species.

\section{Material and methods}

For reasons explained by Enghoff (2014), only adult males were considered. A total of 85 adult Aquattuor males were examined. All specimens are stored in $70 \%$ ethanol and are kept in the Natural History Museum of Denmark, University of Copenhagen (ZMUC). Specimens were examined in $75 \%$ ethanol under a stereo microscope. Numbers of podous rings were counted and midbody vertical diameter measured on complete specimens. Body parts for scanning electron microscopy (SEM) were transferred to $96 \%$ ethanol, then to acetone, air-dried, mounted on aluminium stubs or on triangles of flexible aluminium tape and in turn mounted on stubs, coated with platinum/palladium and studied in a JEOL JSM-6335F scanning electron microscope.

A general description of the genus is provided. The species diagnoses include, inter alia, information on the number of body rings and body diameter. Although it cannot be excluded that specimens falling outside the indicated ranges may be found, this information nevertheless helps to characterize each species. Gonopod terminology is as far as possible as in Enghoff (2014). Because of the great uniformity of Aquattuor species, and because size information and gonopod details are included in the diagnosis, the traditional "Description" paragraph has been replaced by a short note on colouration. Adding more would be redundant.

For the species from the Udzungwa Mts, species of Aquattuor and Chaleponcus (cf. Enghoff 2014) occurring in the same samples and localities are listed under "coexisting species".

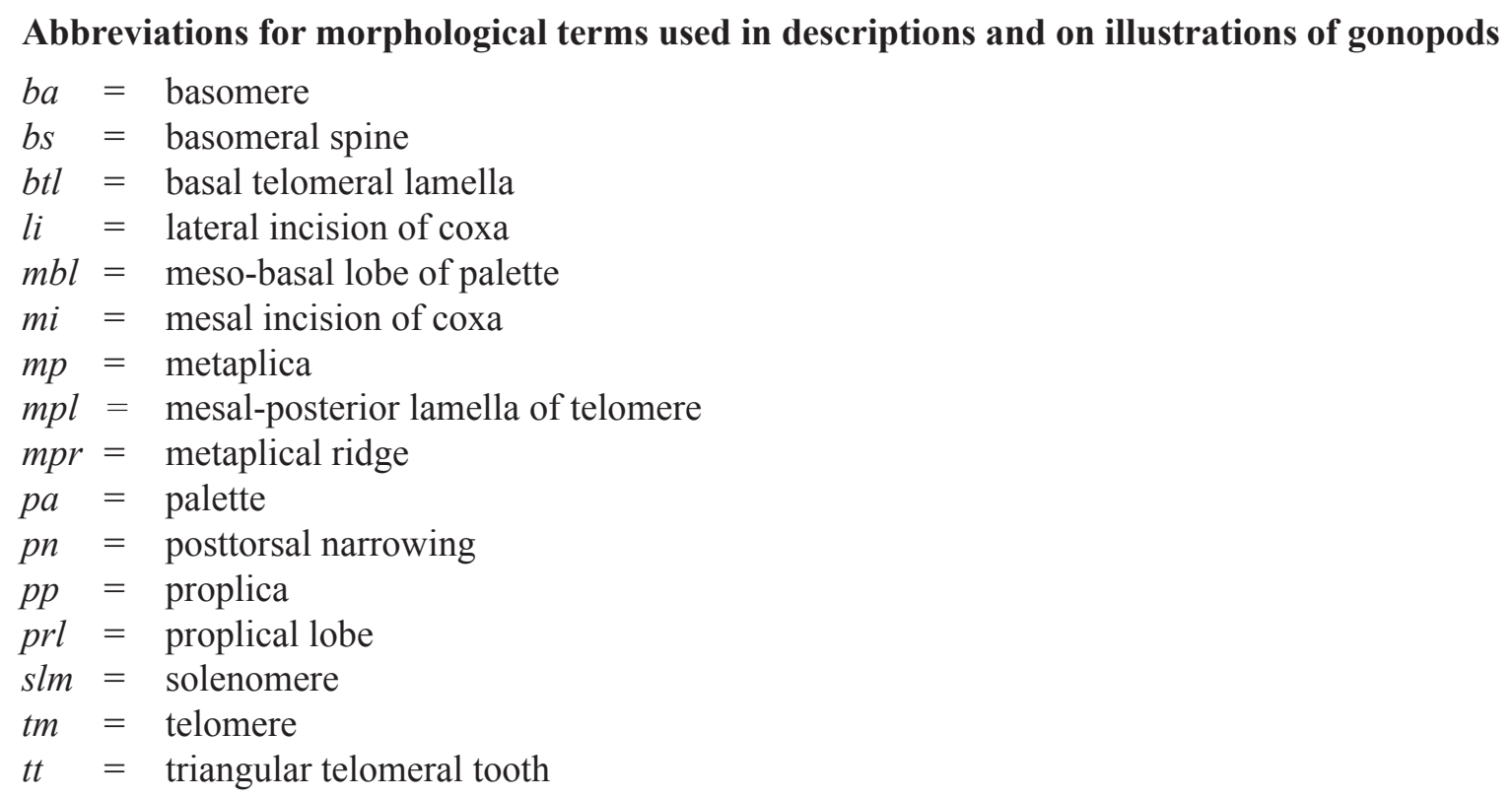




\author{
Abbreviations used in the text, other than abbreviations for morphological terms \\ asl $\quad=$ above sea level \\ $\mathrm{FR}=$ Forest Reserve \\ ZMUC $=$ Zoological Museum, Natural History Museum of Denmark
}

\title{
Results
}

Class Diplopoda Blainville-Gervais, 1844

Order Spirostreptida Brandt, 1833

Family Odontopygidae Attems, 1909

Subfamily Archepyginae Manfredi, 1939

Tribe Prionopetalini Hoffman, 1991

Genus Aquattuor Frederiksen, 2013

This genus was established by Frederiksen (2013b) for the type and until now only species, A. denticulatus (East Usambara Mts, Tanzania). The name is regarded as a masculine noun.

\section{Diagnosis}

A genus of Odontopygidae Prionopetalini in which the gonopodal proplica is apically expanded into a distal 'palette', the metaplica has an oblique flange, the solenomere is simple, thin and whiplike, the telomere terminates in a long, curved gutter-like to tubular part, and the limbus of the body rings consists of large, rectangular, easily detached flaps.

\section{Etymology}

The genus owes its name to the unique limbus flaps which resemble tiny sheets of paper in the standard A4 format.

\section{Description}

This description only applies to males and, as far as non-gonopodal characters are concerned, only includes a selection.

\section{Non-gonopodal characters}

Body LENGTH. 19-35 mm. Midbody vertical diameter $1.4-2.1 \mathrm{~mm}$. 44-54 podous rings, no apodous rings in front of telson. See Fig. 2.

CoLour. Colours of specimens from Udzungwa and East Usambara Mountains all partly or completely faded, leaving only newly collected specimens from Mt. Kilimanjaro with fresh colour (Fig. 1). Light mid-dorsal longitudinal stripe or traces thereof sometimes present, even on faded specimens.

Limbus. Consisting of relatively large $(c .0 .04 \times 0.06 \mathrm{~mm})$ rectangular flaps which are easily detached (Fig. 3D-E).

Telson (Fig. 3B-C). Preanal ring with wrinkled/coriaceous sculpture dorsally. Anal valves with wrinkled/coriaceous sculpture, with a pronounced dorsal denticle and a smaller ventral one, denticles well set off from rest of valve rather than just being "sharp corners". Each valve with three setae. Free margin ("lip") of anal valves raised and provided with three small tubercles on which the setae are borne. 
Gonopods (see Fig. 4)

Coxa. In anterior or posterior view $3 \frac{1}{2}-4 \frac{1}{2} \times$ as long as broad. Margins of proplica $(p p)$ parallel or slightly diverging in basal $c .2 / 3$, apical c. $1 / 3$ set off by mesal $(\mathrm{mi})$ and lateral (li) incisions; apical part of proplica appearing like a rounded "palette" $(\mathrm{pa})$. Proplical lobe ( $\mathrm{prl}$ ) protruding into mesal incision. Metaplica $(\mathrm{mp})$ with irregular surface; at level of mesal and lateral incisions a stout ridge ( $\mathrm{mpr}$ ) running obliquely across metaplica.

Telopodite. Basomere ( $b a$ ) with small spine ( $b s)$ just distal of torsotope (Fig. 11A, C), arculus $90^{\circ}$. Posttorsal narrowing $(p n)$ pronounced (e.g., Figs 5A, 6A). Telopodite beyond $p n$ divided into solenomere $(\mathrm{slm})$ and telomere $(\mathrm{tm})$.

SolenOMERE. Long, thin, whiplike, often resting within telomeral gutter but on preserved specimens frequently free (probably an artefact), apical part with oblique-longitudinal flutings.

Telomere. At base expanded into a complicated basal telomeral lamella $(b t l)$ obscuring origin of solenomere (Fig. 5D). Main part of telomere consisting of a long, narrow lamella folded into a more or less narrow gutter, sometimes even tube-like in distalmost part; gutter/tube describing a $90^{\circ}-360^{\circ}$ curve, usually in almost one plane, but sometimes (A. stereosathe Enghoff sp. nov.) clearly in three dimensions (note: this applies to preserved specimens). Posterior margin of gutter expanded into mesal-posterior lamella $(\mathrm{mpl})$ (e.g., Fig. 5D). Tip of telomere variable: margins smooth or denticulate-laciniate, internal surface of gutter more or less microspiculate (e.g., Fig. 6C-D).

\section{Distribution}

Species of Aquattuor are so far known only from Tanzania. They have been found in several mountain blocks belonging to the Eastern Arc Mts (Burgess et al. 2007): Udzungwa (5 species), Nguru (1 species), Rubeho (1 species) and East Usambara (1 species). One further species has been found on Mt. Kilimanjaro. For an overview, see Figs 12-13.
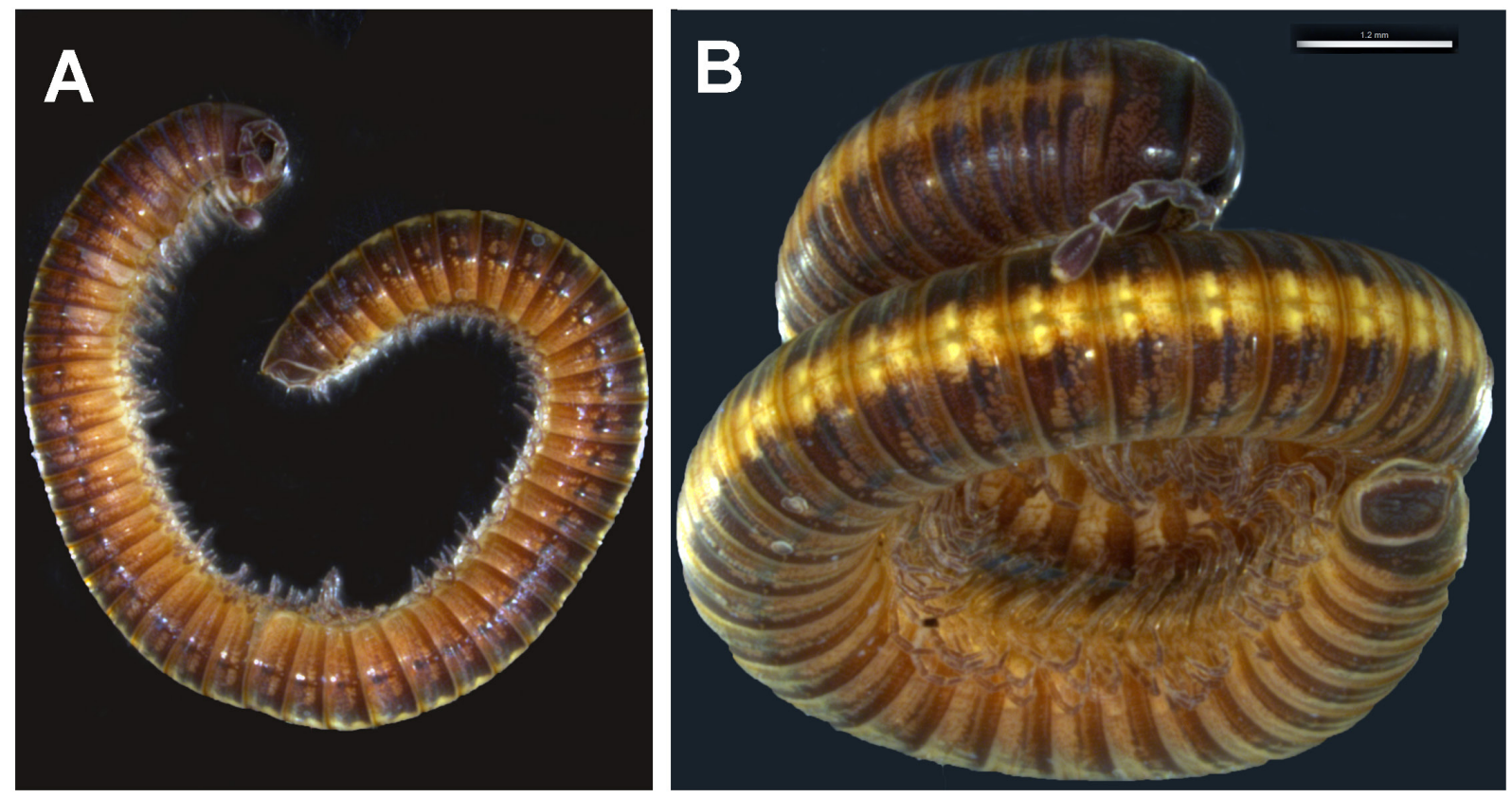

Fig. 1. Aquattuor claudiahempae sp. nov., two paratype $\widehat{\partial} \hat{\jmath}$ after 18 months in alcohol. Scale bar $=$ $1 \mathrm{~mm}$ (B). Photographs by S. Reboleira. 


\section{Intercalary cuticular microscutes}

In A. submajor Enghoff sp. nov. and A. udzungwensis Enghoff sp. nov., intercalary cuticular microscutes, similar to those first reported by Akkari \& Enghoff (2011) in polydesmidan millipedes and subsequently found, inter alia, in the odontopygid genus Chaleponcus Attems, 1914 (Enghoff 2014) and the callipodidan genus Lusitanipus Mauriès, 1978 (Reboleira \& Enghoff 2015), were observed.

\section{Notes on identification}

The species of Aquattuor are all quite similar, even in gonopod structure. In this respect, they form a contrast to the previously treated (much larger) species-swarm centred in the Udzungwa Mts., i.e., the Chaleponcus dabagaensis-group (Enghoff 2014), in which gonopods are highly diverse. Differences between Aquattuor species concern body size (Fig. 2), details of the outline of the gonopod coxa, the curvature of the telomere, the development of the posterior margin of the telomere, and the armature of the telomere tip.

\section{Similar genera}

By far the most diagnostic character of Aquattuor is the large (sub)rectangular-lobed limbus. Subrectangular limbus lobes do occur in certain other odontopygid genera, e.g., Allantogonus Attems, 1912 (Kraus 1960: fig. 5) and Syndesmogenus Attems, 1909 (Kraus 1966: figs 97-99), but in these genera, the lobes are much smaller and are not prone to detachment. The gonopods of Aquattuor, with their long, whip-like solenomere and slender telomere, superficially resemble those of Allantogonus (Kraus 1960:

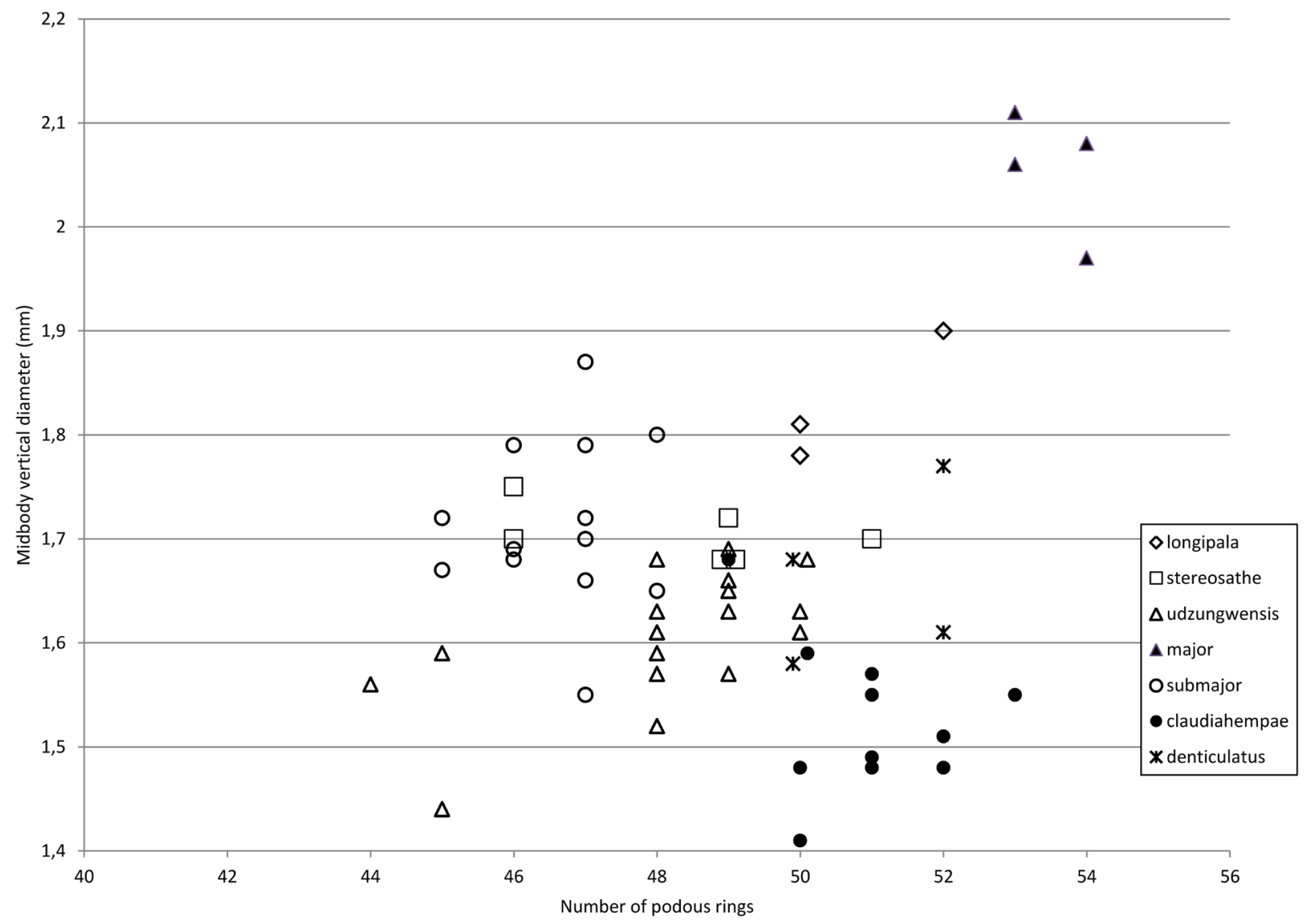

Fig. 2. Body size (numbers of podous rings and midbody vertical diameter) in $\widehat{\partial} \hat{\partial}$ of species of Aquattuor Frederiksen, 2013. In cases of (almost) coinciding values, symbols have been slightly displaced horizontally. 

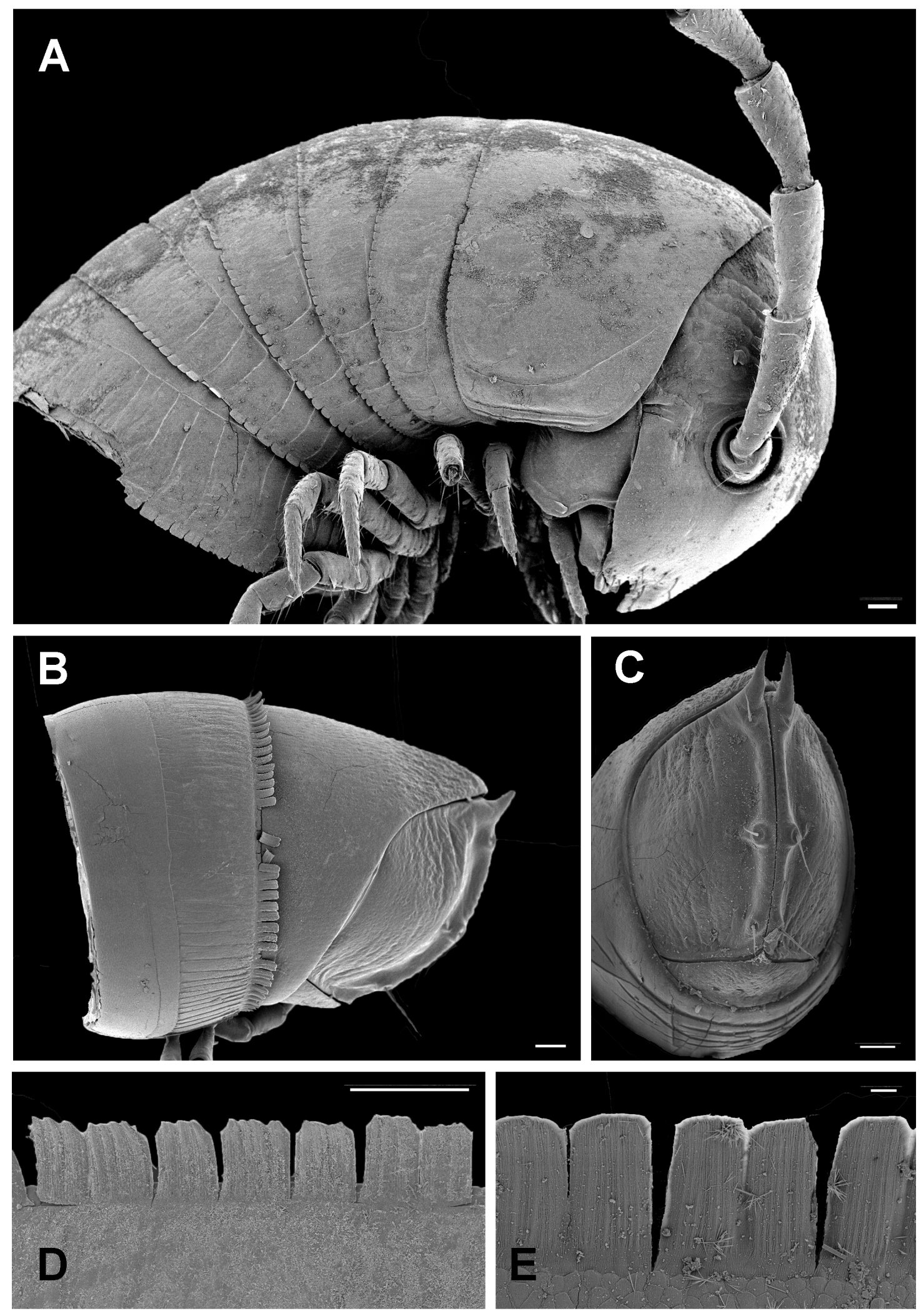

Fig. 3. Aquattuor spp. A. A. stereosathe Enghoff sp. nov., paratype, front end. B-C. A. udzungwensis Enghoff sp. nov., paratype, telson, lateral and posterior view. D-E. A. udzungwensis Enghoff sp. nov., limbus. D. Specimen from West Kilombero Scarp FR. E. Paratype. Scale bars: A-D =0.1 mm; E $=0.01$ $\mathrm{mm}$. 
figs 7, 11, 17) and Lamelloramus Frederiksen, 2013 (Frederiksen 2013: figs 5, 9). However, the coxal apex in Allantogonus is folded basad over the anterior side; the metaplical flange of Lamelloramus is situated completely differently on the median side, and the telomere is either strongly curling up or looping in these genera. The limbus is completely different from that of Aquattuor in both.

Included species (alphabetically)

Aquattuor claudiahempae Enghoff \& Frederiksen sp. nov.

A. denticulatus Frederiksen, 2013 (type species)

A. longipala Enghoff sp. nov.

A. major Enghoff sp. nov.

A. stereosathe Enghoff sp. nov.

A. submajor Enghoff sp. nov.

A. udzungwensis Enghoff sp. nov.

\section{Species from the Udzungwa Mountains}

Aquattuor submajor Enghoff sp. nov. urn:1sid:zoobank.org:act:690C121A-D087-400D-95BC-42BCA7B224BE

Figs $4-5$

\section{Diagnosis}

Diameter $1.55-1.87 \mathrm{~mm}, 45-48$ podous rings. Gonopods: lateral incision of coxa ( $l i)$ absent to poorly developed; apical palette ( $p a$ ) rounded, not longer than broad; telomere describing a $c .270^{\circ}$ curve in almost one plane; mesal-posterior lamella of telomere $(\mathrm{mpl})$ low; anterior margin of telomere without a triangular tooth; telomere tip with finely dentate margins, internal surface microspiculate.

\section{Etymology}

The name is an artificial Latin adjective meaning "below major" and refers to 1) the smaller size of this species compared to A. major Enghoff sp. nov. and 2) the fact that this species occurs at lower altitudes than A. major Enghoff sp. nov.

Material studied (total: 17 ふぇ゙)

\section{Holotype}

TANZANIA: đ̊, Morogoro Region, Udzungwa Mts, Mwanihana FR, above Sanje, 1000 m asl, 18 Aug. 1982, in log, M. Stoltze \& N. Scharff leg. (ZMUC).

\section{Paratypes}

TANZANIA: $7 \widehat{\partial} \widehat{\partial}$, same data as holotype, but in litter, log and pitfall trap, M. Stoltze \& N. Scharff leg. (ZMUC); $1 \hat{\jmath}$, same data but $1100 \mathrm{~m}$ asl, pitfall trap (ZMUC); $8 \hat{\jmath} \widehat{\jmath}$, same data but $1250 \mathrm{~m}$ asl, 1 Aug. 1982, under log, M. Stoltze \& N. Scharff leg. (ZMUC).

\section{Type locality}

TANZANIA: Morogoro Region, Udzungwa Mts, Mwanihana FR, above Sanje, $1000 \mathrm{~m}$ asl.

\section{Colouration}

After 33 years in alcohol faded, only some darker markings on head and collum left. No traces of a middorsal stripe. 

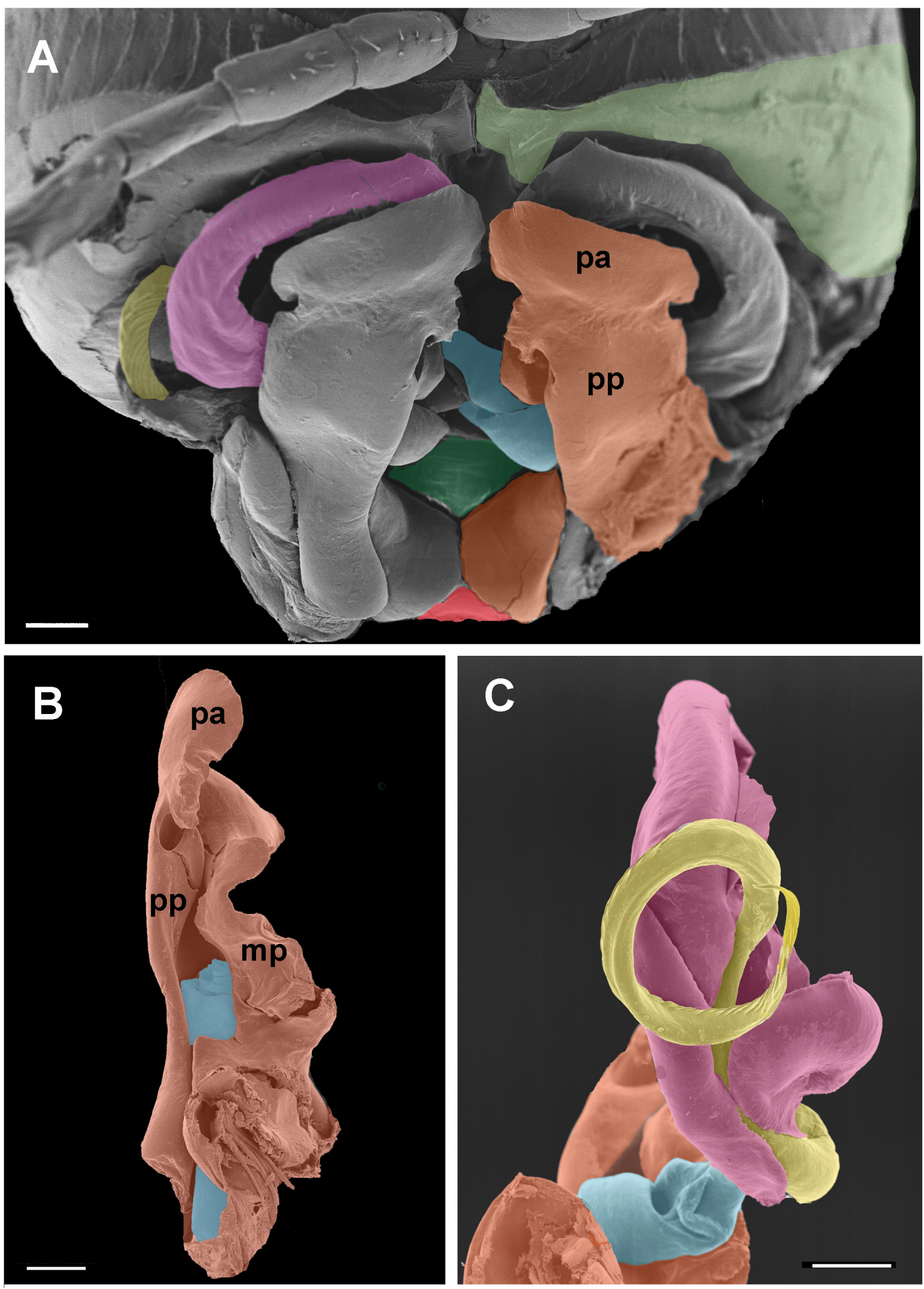

Fig. 4. Aquattuor submajor Enghoff sp. nov., paratype. A. Gonopods in situ, right gonopod coloured. B. Left gonopod coxa and basal part of telopodite. C. Left gonopod telopodite and part of coxa, dorsal (basal) view. Articifical colours: orange $=$ coxa; blue $=$ basomere; yellow $=$ solenomere; pink $=$ telomere; red = gonopod sternum; light green $=$ ventral part of eighth pleurotergite (right side); dark green $=$ sternum of reduced ninth leg-pair. $m p=$ metaplica; $p a=$ palette; $p p=$ proplica. Scale bars $=0.1 \mathrm{~mm}$. 


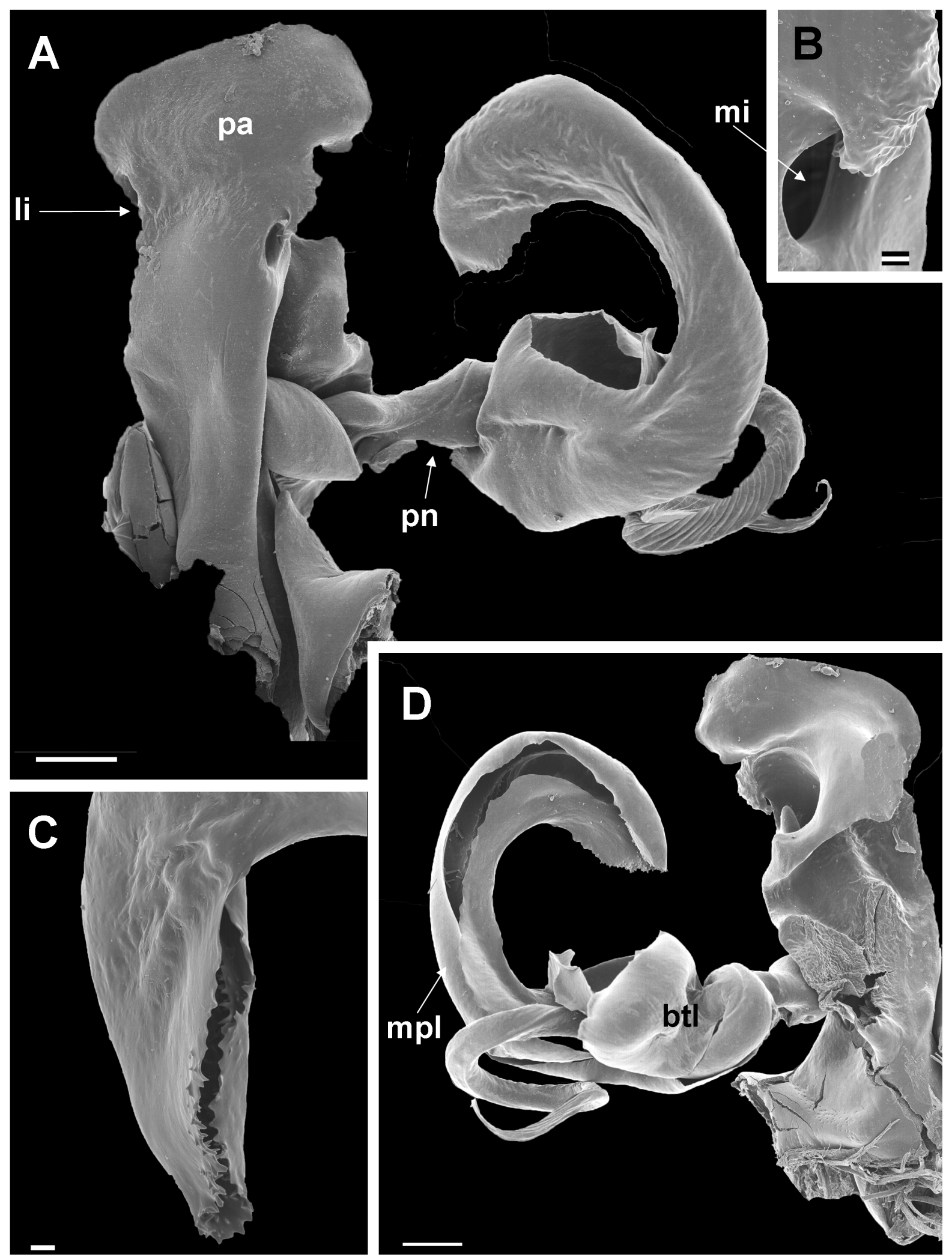

Fig. 5. Aquattuor submajor Enghoff sp. nov., paratype, left gonopod. A. Anterior view. B. Close-up of mesal incision. C. Tip of telomere. D. Posterior view. $b t l=$ basal telomeral lamella; $l i=$ lateral incision; $m i=$ mesal incision; $m p l=$ mesal-posterior lamella of telomere; $p a=$ palette; $p n=$ posttorsal narrowing. Scale bars: A, D $=0.1 \mathrm{~mm}$; $\mathrm{B}-\mathrm{C}=0.01 \mathrm{~mm}$. 


\section{Distribution and habitat}

Known only from Mwanihana FR. Altitudinal range: 1000-1250 m asl.

\section{Coexisting species}

Aquattuor major Enghoff sp. nov. and Chaleponcus mwanihanensis Enghoff, 2014 occur in the same area, but only at higher altitudes.

$$
\begin{gathered}
\text { Aquattuor major Enghoff sp. nov. } \\
\text { urn:1sid:zoobank.org:act:7DE65287-B22D-4470-A2AF-70556B77DEE9 }
\end{gathered}
$$

Fig. 6

\section{Diagnosis}

Diameter 1.97-2.11 mm, 53-54 podous rings. Gonopods: lateral incision of coxa ( $l i$ ) triangular, basally delimited by triangular tooth; apical palette ( $p a$ ) obliquely rounded, much longer than broad; telomere describing an almost $360^{\circ}$ curve in almost one plane; mesal-posterior lamella of telomere $(\mathrm{mpl})$ low; anterior margin of telomere with a triangular tooth $(t t)$; telomere tip with densely microspiculate margins and internal surface.

\section{Etymology}

The name is a Latin adjective meaning "larger" and refers of the larger size of this species, compared to its congeners.

Material studied (total: $4 \hat{\diamond} \widehat{\partial})$

\section{Holotype}

TANZANIA: $\widehat{\jmath}$, Morogoro Region, Udzungwa Mts, Mwanihana FR, 1800-1850 m asl, 25-29 Nov. 1984, pitfall traps, montane rain forest, N. Scharff leg. (ZMUC).

\section{Paratypes}

TANZANIA: 3 ठぇ, Morogoro Region, Udzungwa Mts, Mwanihana FR, above Sanje, $1650 \mathrm{~m}$ asl, 18 Aug. 1982, pitfall trap, M. Stoltze \& N. Scharff leg. (ZMUC).

\section{Type locality}

TANZANIA: Morogoro Region, Udzungwa Mts, Mwanihana FR, 1800-1850 m asl, montane rain forest.

\section{Colouration}

After 31-33 years in alcohol faded, only some darker markings on head and collum left. No traces of a mid-dorsal stripe.

\section{Distribution and habitat}

Known only from Mwanihana FR. Altitudinal range: 1650-1850 m asl. Habitat: montane rain forest.

\section{Coexisting species}

Aquattuor submajor Enghoff sp. nov. and Chaleponcus mwanihanensis Enghoff, 2014 occur in the same area, the former, however, only at lower altitudes. 

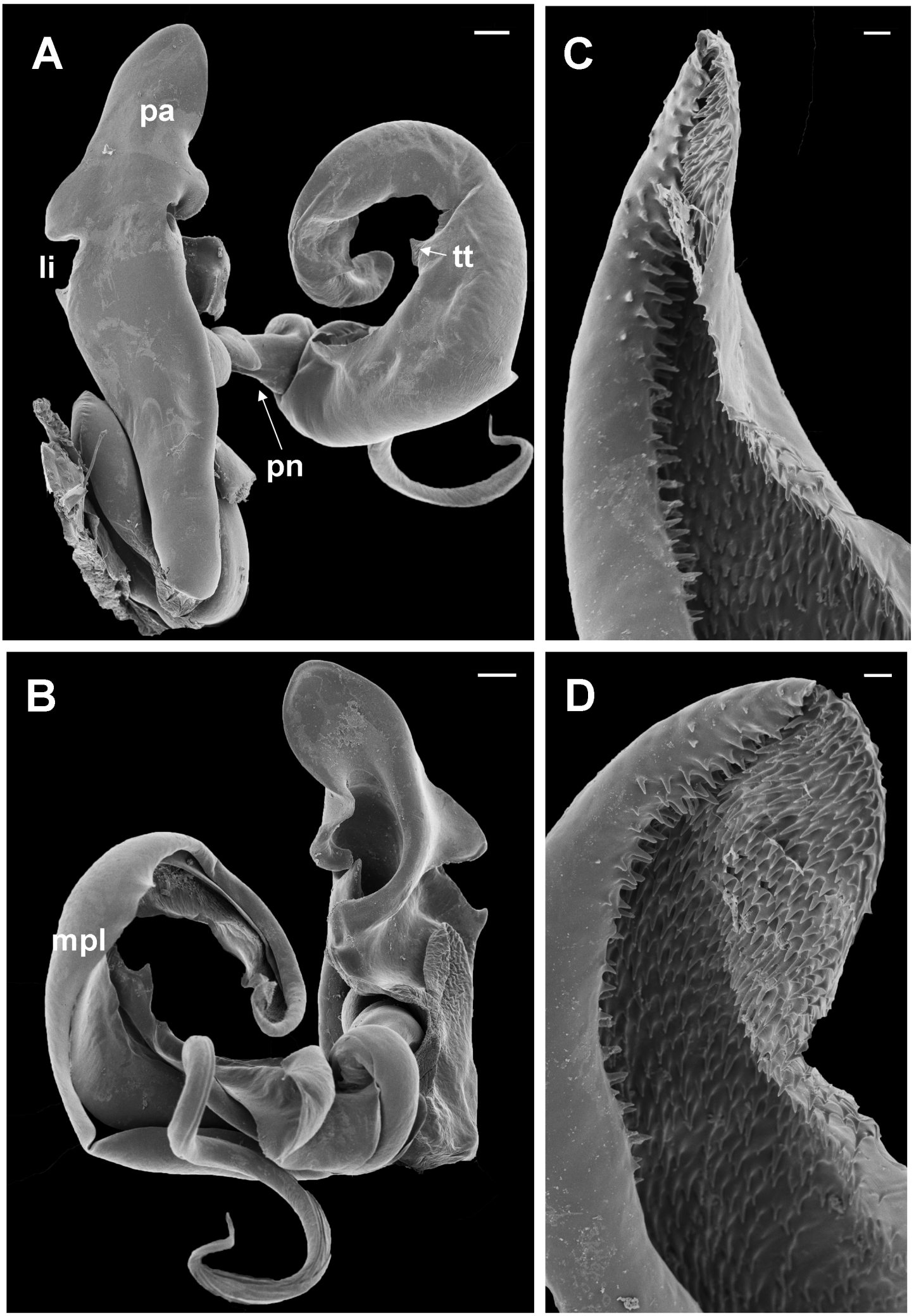

Fig. 6. Aquattuor major Enghoff sp. nov., paratype. A. Left gonopod, anterior view. B. Left gonopod, posterior view. C-D. Telomere tip, two different views. $l i=$ lateral incision; $p a=$ palette; $m p l=$ mesal posterior lamella of telomere; $p n=$ posttorsal narrowing; $t t=$ triangular tooth of telomere. Scale bars: $\mathrm{A}-\mathrm{B}=0.1 \mathrm{~mm} ; \mathrm{C}-\mathrm{D}=0.01 \mathrm{~mm}$. 
Aquattuor longipala Enghoff sp. nov.

urn:1sid:zoobank.org:act:69F309C5-A967-4A68-9776-7C03E879C06D

Fig. 7

\section{Diagnosis}

Diameter 1.78-1.90 mm, 50-52 podous rings. Gonopods: lateral incision of coxa ( $l i$ ) deep with rounded bottom, curving distad, basally delimited by triangular tooth; apical palette $(p a)$ obliquely rounded, much longer than broad; telomere describing a $c .270^{\circ}$ curve in almost one plane; mesal-posterior lamella of telomere $(\mathrm{mpl})$ moderately developed; anterior margin of telomere without a triangular tooth; telomere tip with densely microspiculate margins and internal surface.
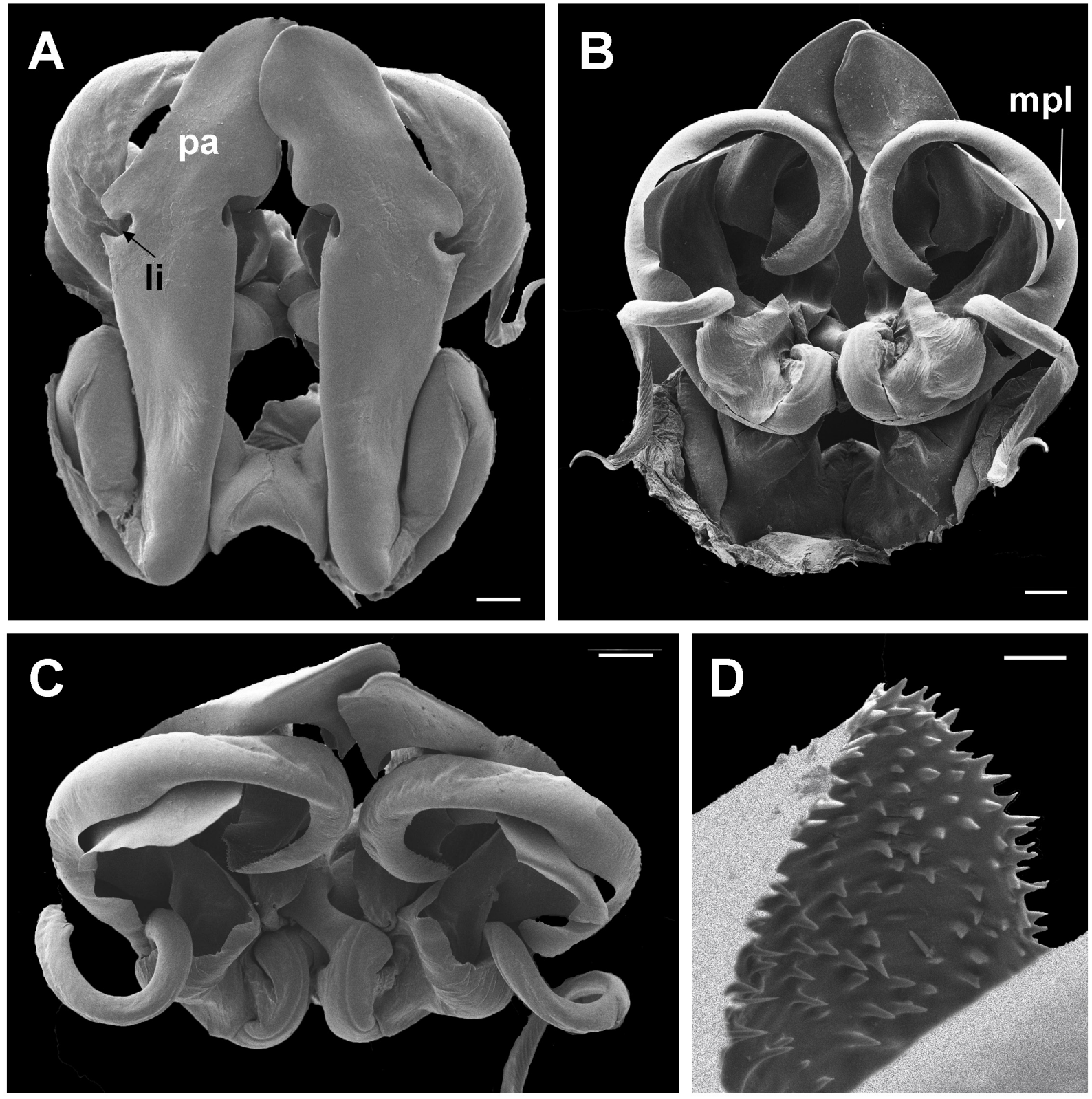

Fig. 7. Aquattuor longipala Enghoff sp. nov., paratype. A. Gonopods, anterior view. B. Gonopods, posterior view. C. Gonopods, oblique apical (central) view. D. Detail of telomere tip. $l i=$ lateral incision; $p a=$ palette; $m p l=$ mesal-posterior lamella of telomere. Scale bars: $\mathrm{A}-\mathrm{C}=0.1 \mathrm{~mm} ; \mathrm{D}=0.01 \mathrm{~mm}$. 


\section{Etymology}

The name is a Latin noun, here in apposition, composed of longi- (long) and pala (palette), and refers to the shape of the apical part of the gonopod coxa.

Material studied (total: 3 ふふ)

Holotype

TANZANIA: đo, Iringa Region, Iringa District, Udzungwa Mts, West Kilombero Scarp FR, 0750’38.4" S, 36²2'17.6” E, montane forest, 1390-1410 m asl, plot Paradiso, 18 Nov. 2000, Frontier Tanzania leg. (ZMUC).

\section{Paratypes}

TANZANIA: $2 \widehat{\jmath}$, same data as holotype (ZMUC).

\section{Type locality}

TANZANIA: Iringa Region, Iringa District, Udzungwa Mts, West Kilombero Scarp FR, 0750’38.4” S, $36^{\circ} 22^{\prime} 17.6$ ' E, montane forest, 1390-1410 m asl.

\section{Colouration}

After 15 years in alcohol still with a clear mid-dorsal, light longitudinal band, flanked by darker areas. Head and collum with some dark markings.

\section{Distribution and habitat}

Known only from West Kilombero Scarp FR. Altitudinal range: 1390-1410 m. Habitat: montane forest.

\section{Coexisting species}

Aquattuor udzungwensis Enghoff sp. nov., Chaleponcus netus Enghoff, 2014, and C. circumvallatus Enghoff, 2014 were found in the same sample as A. longipala Enghoff sp. nov. In addition, C. basiliscus Enghoff, 2014, C. gracilior Enghoff, 2014, C. ibis Enghoff, 2014, and C. tintin Enghoff, 2014 were found in West Kilombero Scarp FR.

Aquattuor udzungwensis Enghoff sp. nov.

\section{urn:1sid:zoobank.org:act:60F38BFF-E5EA-4BB0-A691-263DB097502B}

Figs 3,8

\section{Diagnosis}

Diameter 1.44-1.69 mm, 44-50 podous rings. Gonopods: lateral incision of coxa (li) deep with rounded bottom, curving distad; apical palette ( $p a$ ) rounded-triangular, not longer than broad; telomere describing a c. $270^{\circ}$ curve in almost one plane; mesal-posterior lamella of telomere $(\mathrm{mpl})$ high, basally set off by $45-90^{\circ}$ angle; anterior margin of telomere without a triangular tooth; telomere tip with smooth to microspiculate margins, internal surface microspiculate.

\section{Etymology}

The name is a Latin adjective derived from the Udzungwa Mts, home of this (and several other) Aquattuor species.

Material studied (total: 21 ふふ)

\section{Holotype}

TANZANIA: $\widehat{\jmath}$, Udzungwa Mts, Iringa Region, Udzungwa Scarp FR, above Chita village, $750 \mathrm{~m}$ asl, 23 Oct. -14 Nov. 1984, lowland rain forest, N. Scharff leg. (ZMUC). 

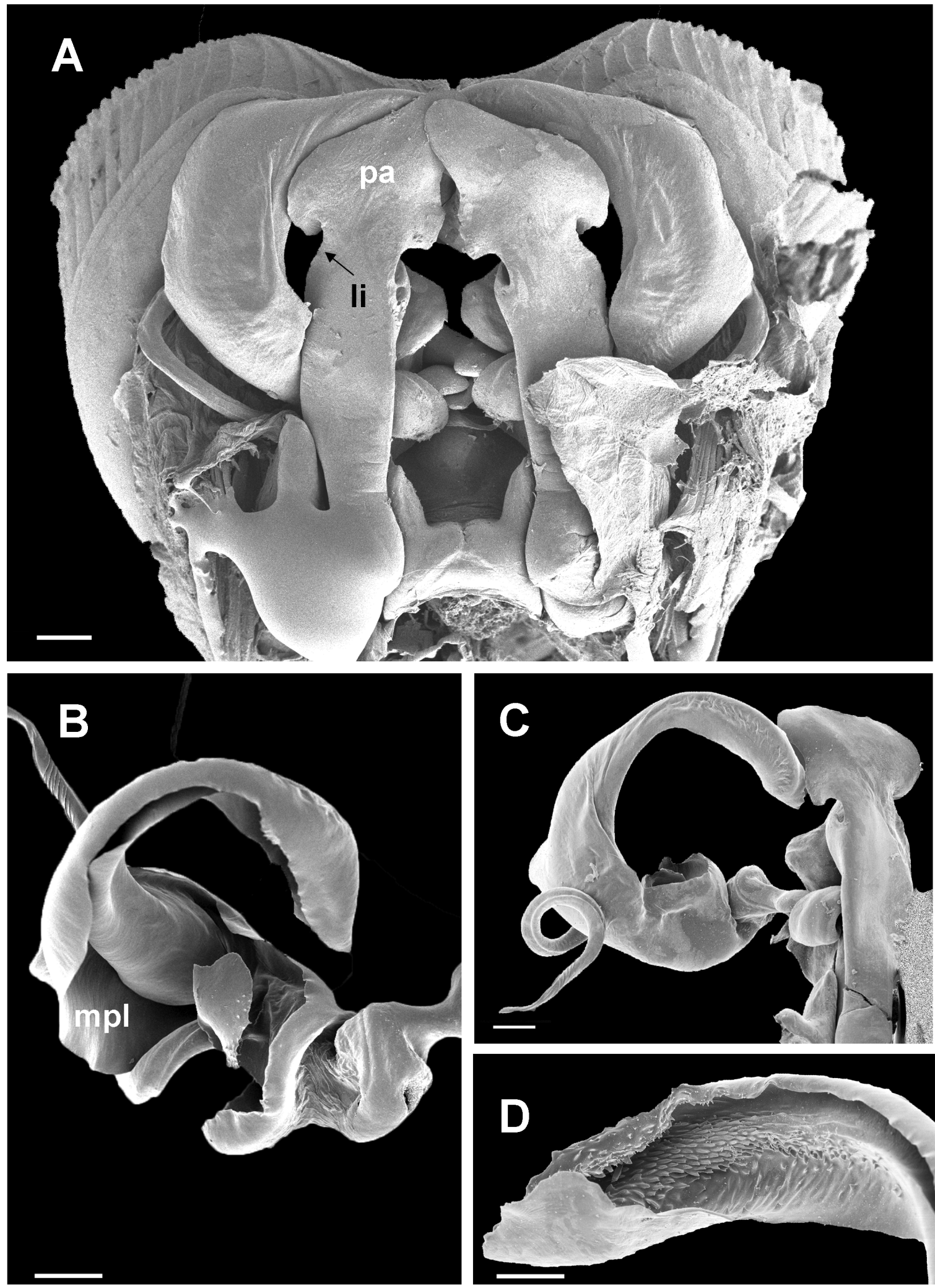

Fig. 8. Aquattuor udzungwensis Enghoff sp. nov. A-B, D. Paratype. C. Specimen from West Kilombero Scarp FR. A. Gonopods in situ. B. Telopodite, ventral view. C. Right gonopod, anterior view. D. Telomere tip. $l i=$ lateral incision; $p a=$ palette; $m p l=$ mesal-posterior lamella of telomere. Scale bars: $\mathrm{A}-\mathrm{C}=0.1 \mathrm{~mm} ; \mathrm{D}=0.05 \mathrm{~mm}$. 


\section{Paratypes}

TANZANIA: 4 ふぇ, same data as holotype, but 25-29 Oct. 1984, pitfall traps (ZMUC).

\section{Referred non-type material}

TANZANIA: Iringa Region, Iringa District, Udzungwa Mts, West Kilombero Scarp FR, montane forest, Frontier Tanzania coll.: 1 ơ, $07^{\circ} 53^{\prime} 19.5$ " S, 36 23 '11.6” E, 1100-1300 m asl, Plot Ukami, 30

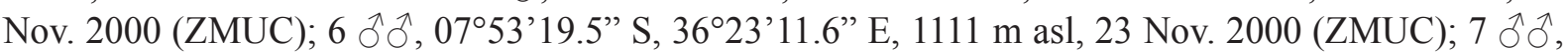

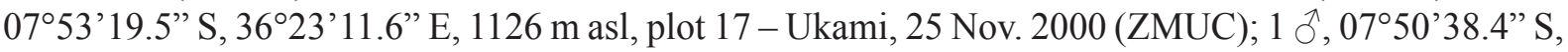

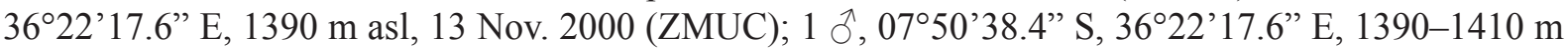
asl, Plot Paradiso, 18 Nov. 2000 (ZMUC).

\section{Type locality}

TANZANIA: Udzungwa Mts, Iringa Region, Udzungwa Scarp FR, above Chita village, $750 \mathrm{~m}$ asl, lowland rain forest.

\section{Colouration}

After 15-31 years in alcohol faded, pale yellowish, head and especially collum contrastingly darker. Traces of paramedian, dark bands flanking a middorsal, pale stripe.

\section{Distribution and habitat}

Known from Udzungwa Scarp FR and from West Kilombero Scarp FR. Altitudinal range: 750-1410 m. Habitat: lowland rain forest and montane rain forest.

\section{Coexisting species}

In Udzungwa Scarp FR, Aquattuor stereosathe Enghoff sp. nov., Chaleponcus circumvallatus Enghoff, 2014, C. hamerae Enghoff, 2014, and C. nikolajscharffi Enghoff, 2014 have been found. In West Kilombero Scarp FR, Aquattuor longipala Enghoff sp. nov., Chaleponcus netus Enghoff, 2014, and C. circumvallatus Enghoff, 2014 were found in the same sample as A. udzungwensis Enghoff sp. nov. In addition, C. basiliscus Enghoff, 2014, C. gracilior Enghoff, 2014, C. ibis Enghoff, 2014, and C. tintin Enghoff, 2014 were found in West Kilombero Scarp FR.

Aquattuor stereosathe Enghoff sp. nov. urn:1sid:zoobank.org:act:15CD343E-ABFB-400A-89A0-B25B26E2344C

Figs 3,9

\section{Diagnosis}

Diameter $1.68-1.75 \mathrm{~mm}, 46-51$ podous rings. Gonopods: lateral incision of coxa (li) broad, shallow, with rounded bottom, basally delimited by triangular tooth; apical palette $(p a)$ rounded, not longer than broad; telomere describing a $360^{\circ}$ curve in three dimensions; mesal-posterior lamella of telomere $(\mathrm{mpl})$ low; anterior margin of telomere without a triangular tooth; telomere tip with coarsely laciniate margins, internal surface smooth.

\section{Etymology}

The name is a Greek noun, here in apposition, composed of stereo-, which refers to the threedimensionality of the curvature of the telomere, and sathe, literally meaning "penis", here referring to the telomere. 


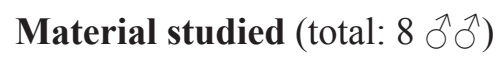

Holotype

TANZANIA: ${ }^{\Uparrow}$, Iringa Region, Udzungwa Mts, Udzungwa Scarp FR, above Chita village, $1500 \mathrm{~m}$ asl, 2-13 Nov.1984, N. Scharff leg. (ZMUC).
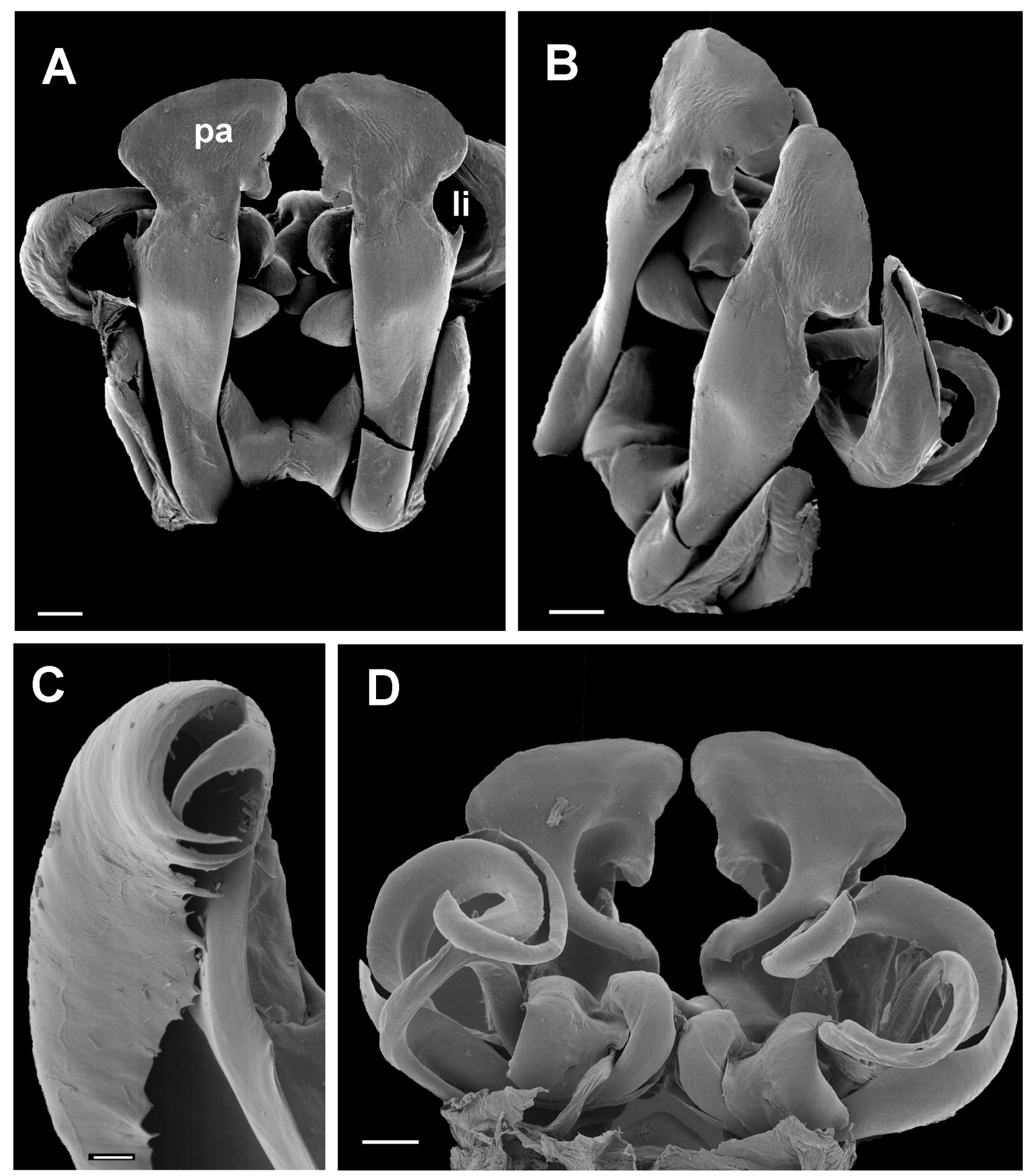

Fig. 9. Aquattuor stereosathe Enghoff sp. nov., paratype. A. Gonopods, anterior view. B. Gonopods, oblique lateral view. C. Tip of telomere. D. Gonopods, posterior view. $l i=$ lateral incision; $p a=$ palette. Scale bars: $\mathrm{A}-\mathrm{C}=0.2 \mathrm{~mm} ; \mathrm{D}=0.01 \mathrm{~mm}$. 
Paratypes

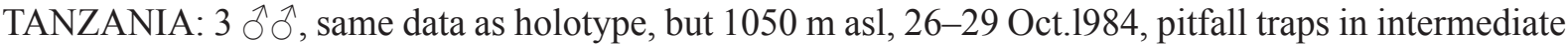
rain forest (ZMUC); $1 \widehat{\jmath}$, same data, but $1400 \mathrm{~m}$ asl, 4-5 Nov. 1984 (ZMUC); 3 $\widehat{\partial}$, Iringa Region, Udzungwa Mts, Udzungwa Scarp FR, Luhega Forest, 08²3' S, 3559’ E, 900 m asl, 15 Jul.1990, J. Lovett, E. Mulungu \& L. Hansen leg.

\section{Type locality}

TANZANIA: Iringa Region, Udzungwa Mts, Udzungwa Scarp FR, above Chita village, $1500 \mathrm{~m}$ asl.

\section{Colouration}

After 25-31 years in alcohol still with a clear mid-dorsal, light longitudinal band, flanked by darker areas. Head and collum with some dark markings.

\section{Distribution and habitat}

Known only from Udzungwa Scarp FR. Altitudinal range: 900-1500 m. Habitat: (intermediate) rain forest.

\section{Coexisting species}

In Udzungwa Scarp FR, Aquattuor udzungwensis Enghoff sp. nov., Chaleponcus circumvallatus Enghoff, 2014, C. hamerae Enghoff, 2014, and C. nikolajscharffi Enghoff, 2014 have been found.

\section{Species from areas other than the Udzungwa Mountains}

In addition to the Udzungwa Mts, species of Aquattuor have been collected in the East Usambara, Nguru and Rubeho Mts, which all belong to the Eastern Arc Mountains (Burgess et al. 2007), and on Mt. Kilimanjaro, a much younger, volcanic mountain (Nonnotte et al. 2008).

\section{Aquattuor claudiahempae sp. nov. urn:1sid:zoobank.org:act:66387356-4B9A-467E-A3CA-4BC76EF8FCAE}

Figs 1,10

\section{Diagnosis}

Diameter $1.41-1.58 \mathrm{~mm}, 50-53$ podous rings. Gonopods: lateral incision of coxa ( $\mathrm{li}$ ) poorly developed; apical palette $(\mathrm{pa})$ subquadratic, with well-developed meso-basal lobe $(\mathrm{mbl})$; telomere describing a c. $270^{\circ}$ curve in almost one plane; mesal-posterior lamella of telomere $(\mathrm{mpl})$ low; anterior margin of telomere without a triangular tooth; telomere tip densely microspiculate, margin microserrate.

\section{Etymology}

The name is a feminine noun in the genitive, referring to Claudia Hemp, Würzburg, project leader of the DFG research group Kilimanjaro, in acknowledgement of her great support.

Material studied (total: $26 \lesssim ふ$ )

\section{Holotype}

TANZANIA: ${ }^{\curvearrowright}$, Kilimanjaro Region, Hai District, Mt. Kilimanjaro, 0316’07.05” S, 37¹8’28.68” E, homegarden plot 2, $1169 \mathrm{~m}$ asl, 26 Nov. 2013, S.B. Frederiksen leg. (ZMUC).

\section{Paratypes}

TANZANIA: Kilimanjaro Region, Mt. Kilimanjaro: $8 \hat{\jmath} \widehat{\jmath}$, same data as holotype (ZMUC); $1 \hat{\jmath}$, same

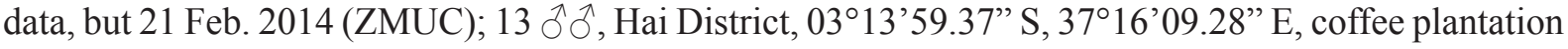



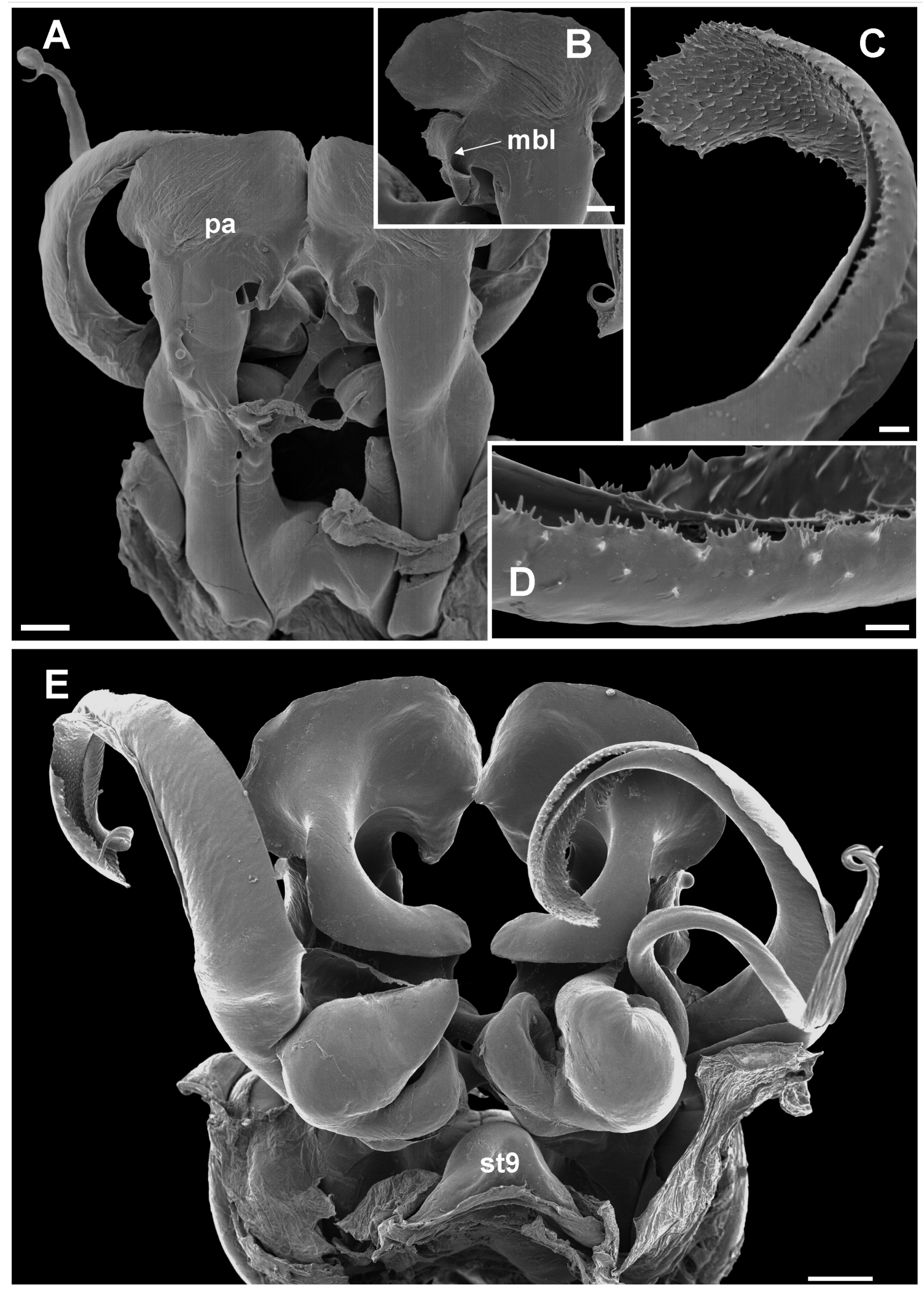

Fig. 10. Aquattuor claudiahempae sp. nov., paratype. A. Gonopods, anterior view. B. Right palette, showing well developed meso-basal lobe. C. Telomere tip. D. Margin of telomere tip. E. Gonopods, poterior view. $m b l=$ mesobasal lobe of palette; $p a=$ palette; $s t 9=$ sternum of rudimentary $9^{\text {th }}$ leg-pair. Scale bars: $A, E=0.1 \mathrm{~mm} ; \mathrm{B}=0.05 \mathrm{~mm} ; \mathrm{C}=0.02 \mathrm{~mm} ; \mathrm{D}=0.01 \mathrm{~mm}$. 
plot 2, 1345 m asl, 20 Nov. 2013, S.B. Frederiksen leg. (ZMUC); 1 ð’, Hai District, 03¹4’34.66” S, $37^{\circ} 15^{\prime} 03.91^{\prime \prime}$ E, coffee plantation plot 2, $1306 \mathrm{~m}$ asl, 11 Mar. 2014, S.B. Frederiksen leg. (ZMUC); 1 ,

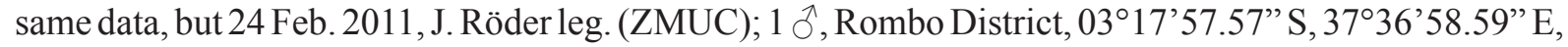
grassland plot 5, $1303 \mathrm{~m}$ asl, 16 Nov. 2011, J. Röder leg. (ZMUC).

\section{Type locality}

TANZANIA: Kilimanjaro Region, Hai District, Mt. Kilimanjaro, $03^{\circ} 16^{\prime} 07.05^{\prime}$ S, 37²1 ’28.68” E, 1169 m asl.

\section{Colouration}

Mostly brown, darker on the dorsal side, with a clear mid-dorsal, yellow longitudinal band, lighter yellowish on the ventral side; legs, head, collum and telson mostly brown (Fig. 1).

\section{Distribution and habitat}

Known only from Mt. Kilimanjaro in habitats disturbed by human activities: chagga homegardens (Soini 2005) and coffee plantations. The grassland plot where one specimen was collected is used for fodder harvest and is thus also under human influence. Altitudinal range: $1169-1345 \mathrm{~m}$ asl.

Material studied (total: 1 đ)

Aquattuor aff. claudiahempae sp. nov.

TANZANIA: 1 , Morogoro Region, Kilosa District, Rubeho Mts, $5 \mathrm{~km}$ SW of Madizini, $900 \mathrm{~m}$ asl, 10-24 Sep. 1983, M. Andersen leg. (ZMUC).

\section{Remarks}

Diameter $1.68 \mathrm{~mm}, 49$ podous rings. Colouration faded. Apart from its larger diameter, this specimen looks completely like $A$. claudiahempae sp. nov., despite the $350 \mathrm{~km}$ distance between the two sites (cf. Discussion).

\section{Aquattuor denticulatus Frederiksen, 2013}

Fig. 11

\section{Diagnosis}

Diameter $1.58-1.77 \mathrm{~mm}, 50-52$ podous rings. Gonopods: lateral incision of coxa (li) deep, basally delimited by triangular tooth; apical palette $(p a)$ rounded, not longer than broad; telomere bending $90^{\circ}$ distal after basal lamella, tip of telomere curving laterad (towards coxa); mesal-posterior lamella of telomere $(\mathrm{mpl})$ low; anterior margin of telomere without a triangular tooth; telomere tip densely microspiculate.

\section{Etymology}

The name refers to the microspiculate (denticulate) telomeral tip (Frederiksen 2013).

Material studied (total: $5 \widehat{\diamond} \overbrace{}^{\Uparrow})$

Holotype

TANZANIA: ${ }^{\lambda}$, East Usambara Mts, Amani, 1000 m asl, 20 Jul.1980, M. Stoltze \& N. Scharff leg. (ZMUC 00020529).

\section{Paratypes}

TANZANIA: East Usambara Mts, Amani: 1 ô, 500 m asl, 7 Feb. 1977, H. Enghoff, O. Lomholdt \& O. Martin leg. (ZMUC 00020528); 1 Ō, $1000 \mathrm{~m}$ asl, 27 Jan.1977, H. Enghoff, O. Lomholdt \& O. 

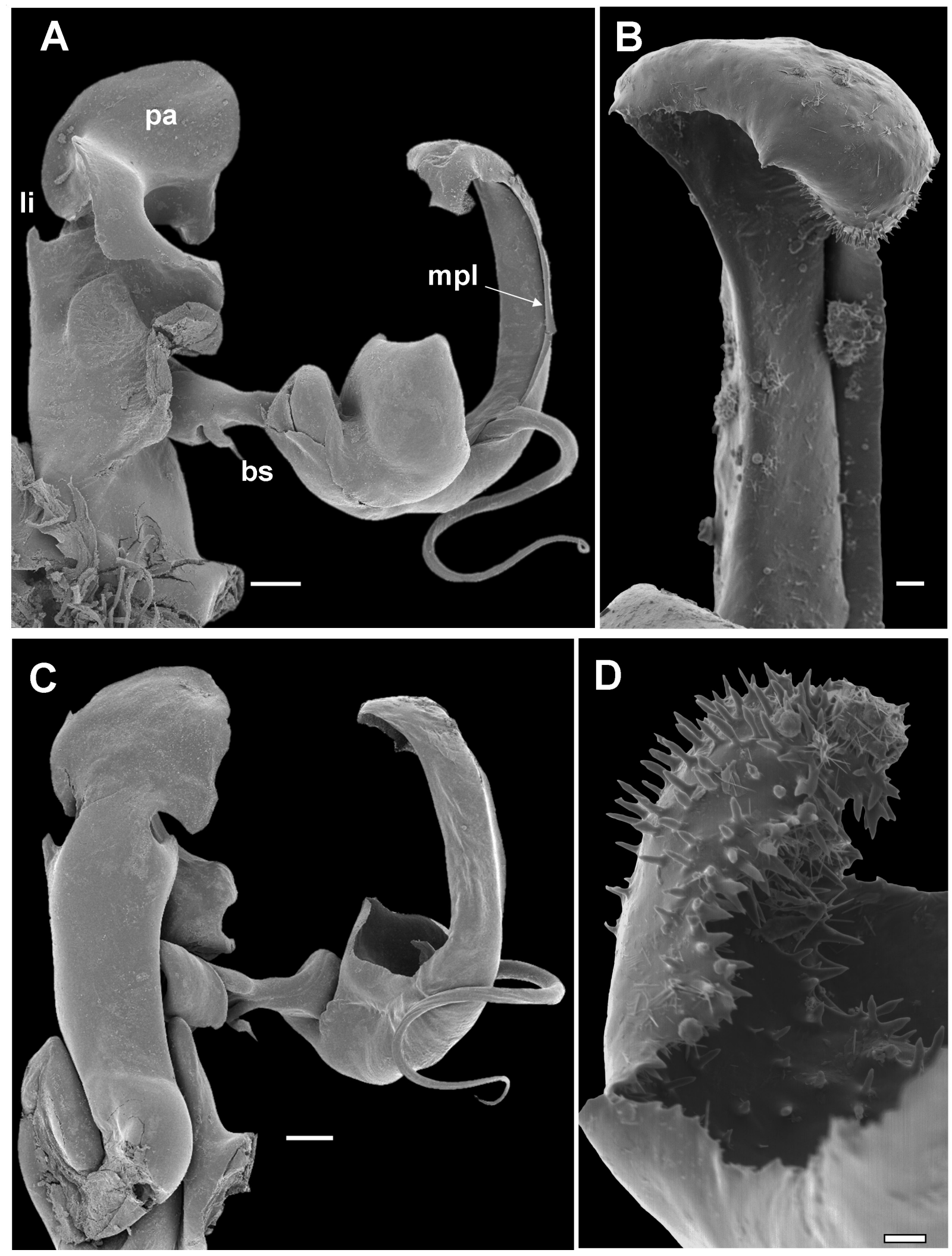

Fig. 11. Aquattuor denticulatus Frederiksen, 2013, paratype. A. Gonopods, posterior view. B. Telomere, distal part, lateral view. C. Gonopods, anterior view. D. Telomere tip. $l i=$ lateral incision; $b s=$ basomeral spine; $p a=$ palette; $m p l=$ mesal-posterior lamella of telomere. Scale bars: $\mathrm{A}, \mathrm{C}=0.1 \mathrm{~mm} ; \mathrm{B}=0.02 \mathrm{~mm}$; $\mathrm{D}=0.01 \mathrm{~mm}$. 
Martin leg. (ZMUC 00020530); 1 ð̊, 1000 m asl, 15 Jul. 1979, M. Stoltze leg. (ZMUC 00021429); 1 ð,, $1000 \mathrm{~m}$ asl, 28 Dec. 1975, E. Wederkinch leg. (ZMUC 00020610).

\section{Type locality}

TANZANIA: East Usambara Mts, Amani, 1000 m asl.

\section{Colouration}

After 35-40 years in alcohol, colouration faded, yellowish brown with no clear markings.

\section{Distribution and habitat}

Known only from the East Usambara Mts. Altitudinal range: 500-1000 m asl. Habitat: lower montane forest.

\section{Aquattuor sp.}

Material studied (total: 1 )

TANZANIA: 1 +, Nguru Mts, Mhonda Mission at Turiani, Oct. 1992, M. Andersen leg. (ZMUC).

\section{Remarks}

The characteristic limbus places this specimen in Aquattuor, but in the absence of a male, the identity of the species remains obscure. The Nguru Mts are located roughly midway between the Udzungwa and the Usambara Mts.

\section{Key to species of Aquattuor Frederiksen, 2013}

The key is based on adult males. The diameter and number of podous rings are not absolute characters newly collected specimens may fall outside the ranges (and because of the positive correlation between number of rings and diameter, if a specimens falls outside in one parameter, it is likely to fall outside in the other as well). Differences between species are subtle, and specimens should be carefully compared with the diagnoses and illustrations. Specimens collected in new localities are likely to represent new species.

1. Palette (pa) of gonopods elongate, much longer than broad (Figs 6A, 7A); 50+ podous rings, diameter $>1.7 \mathrm{~mm}$

- Palette as long as broad or slightly longer (Figs 5A, 8A, 9A, 10A, 11A); diameter $<1.9 \mathrm{~mm} \ldots . .3$

2. 53-54 podous rings, diameter $>1.9 \mathrm{~mm}$; anterior margin of telomere with a triangular tooth (Fig. 6A, $t t$ ) A. major Enghoff sp. nov. (Udzungwa: Mwanihana)

- 50-52 podous rings, diameter $\leq 1.9 \mathrm{~mm}$; anterior margin of telomere without triangular tooth A. longipala Enghoff sp. nov. (Udzungwa: W Kilombero Scarp)

3. Subdistal part of telomere almost straight, parallel to coxite, telomere tip bent abruptly lateral (Fig. 11); 50-52 podous rings, diameter $1.6-1.8 \mathrm{~mm}$

A. denticulatus Frederiksen, 2013 (E Usambara)

- Telomere describing a smoother curve (Figs 5A, D, 8B-C, 9C, 10E) .4

4. Telomere describing a $c .360^{\circ}$ curve, curving in three dimensions; telomere tip with serrate margins, but surface not microspiculate ......A. stereosathe Enghoff sp. nov. (Udzungwa: Udzungwa Scarp)

- Telomere describing a $c .270^{\circ}$ curve, curving almost in one plane only; telomere tip with microspiculate surface 
5. Lateral incision ( $l i)$ of gonopod coxa deep, apical palette ( $p a$ ) rounded-triangular (Fig. 8A); $\leq 50$ podous rings, diameter $\leq 1.7 \mathrm{~mm}$

A. udzungwensis Enghoff sp. nov. (Udzungwa: Udzungwa Scarp, W Kilombero Scarp)

- Lateral incision $(l i)$ indistinct

6. Palette ( $p a)$ of gonopods subquadratic, with well-developed meso-basal lobe ( $m b l$ ) (Fig. 10A-B); $50-53$ podous rings, diameter $1.4-1.6 \mathrm{~mm}$ A. claudiahempae sp. nov. (Mt. Kilimanjaro)

- Palette more rounded, meso-basal lobe small (Fig. 5A-B); 45-48 podous rings, diameter $1.5-1.9 \mathrm{~mm}$ A. submajor Enghoff sp. nov. (Udzungwa: Mwanihana)

\section{Discussion}

Although by far most of the available material of Aquattuor species is from the Udzungwa Mts, the genus has also been found in the East Usambara, Nguru and Rubeho Mts, all part of the Eastern Arc

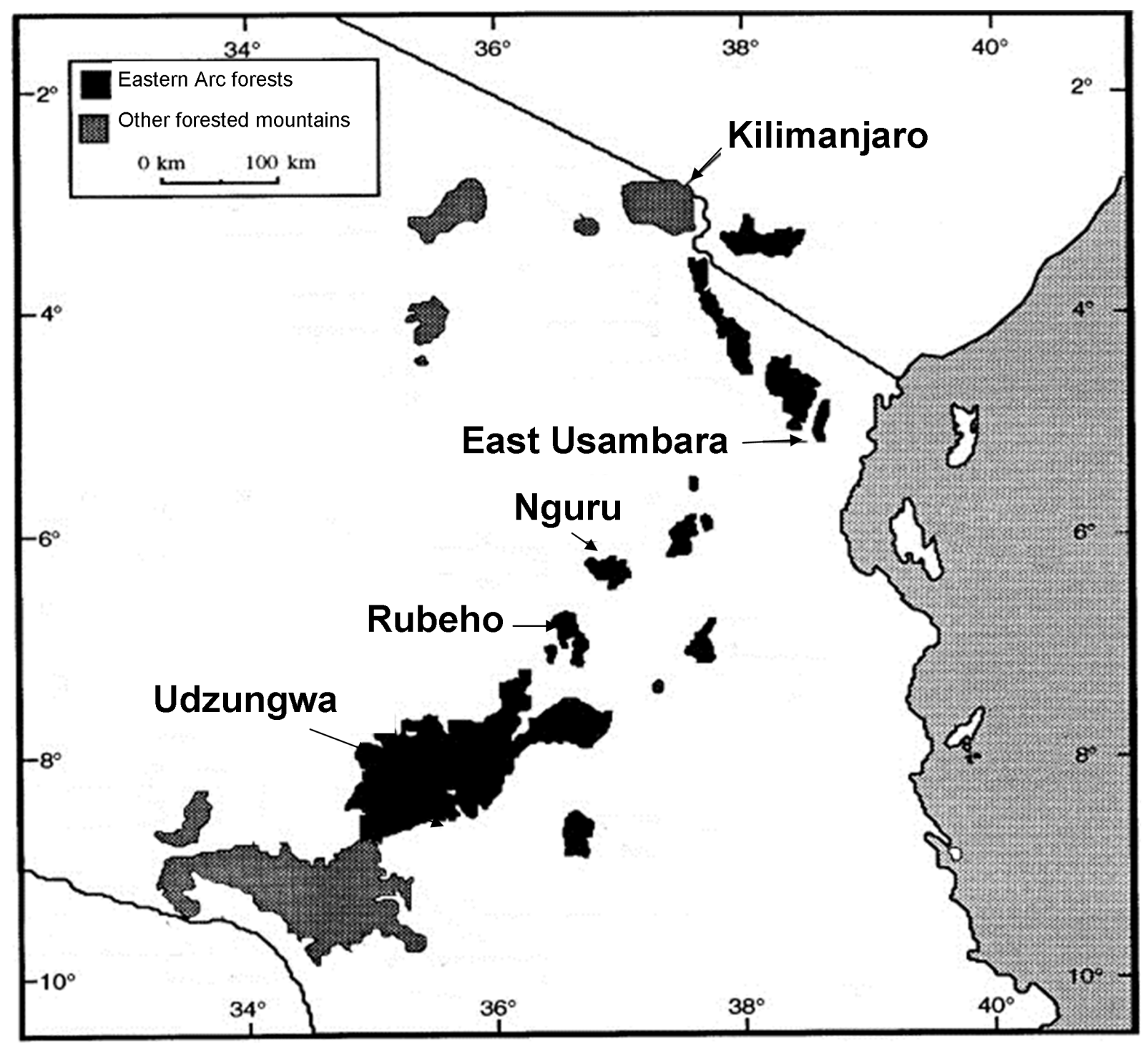

Fig. 12. Map of part of Tanzania showing the mountains where Aquattuor species have been found. Based on Burgess et al. (2007: fig. 1). 
(Figs 12-13), and it is quite likely that Aquattuor will be discovered elsewhere in this ancient mountain system. The occurrence of $A$. claudiahempae sp. nov. on Mt. Kilimanjaro appears to be an anomaly, and three lines of evidence suggest that this species may have been introduced into Mt. Kilimanjaro: 1) it occurs only in disturbed habitats, 2) one specimen which is virtually identical to A. claudiahempae sp. nov. has been found in the Rubeho Mts, $350 \mathrm{~km}$ from Mt. Kilimanjaro, and 3) A. claudiahempae sp. nov. was not collected during earlier explorations of Mt. Kilimanjaro, including the rather large-scale Sjöstedt Expedition (Attems 1909).

\section{Acknowledgements}

SBF was sponsored by the Research-Unit 1246 (https://www.kilimanjaro.biozentrum.uni-wuerzburg. de/) of the German Research Foundation (DFG). We are particularly grateful to Claudia Hemp for making this possible. Research permits were granted by COSTECH, TAWIRI and TANAP (permits nos 2011-346-ER-96-44 and 2014-305-ER-96-44). This work would not have been possible at all without the impressive collections made by Frontier Tanzania. Our sincere thanks are due to this NGO, as well as to Nikolaj Scharff and other colleagues at the Natural History Museum of Denmark, and to Juliane Röder, University of Marburg, who all collected important material and provided various advice, as well as to Sofia Reboleira, Natural History Museum of Denmark, who provided the photograph in Fig. 1.

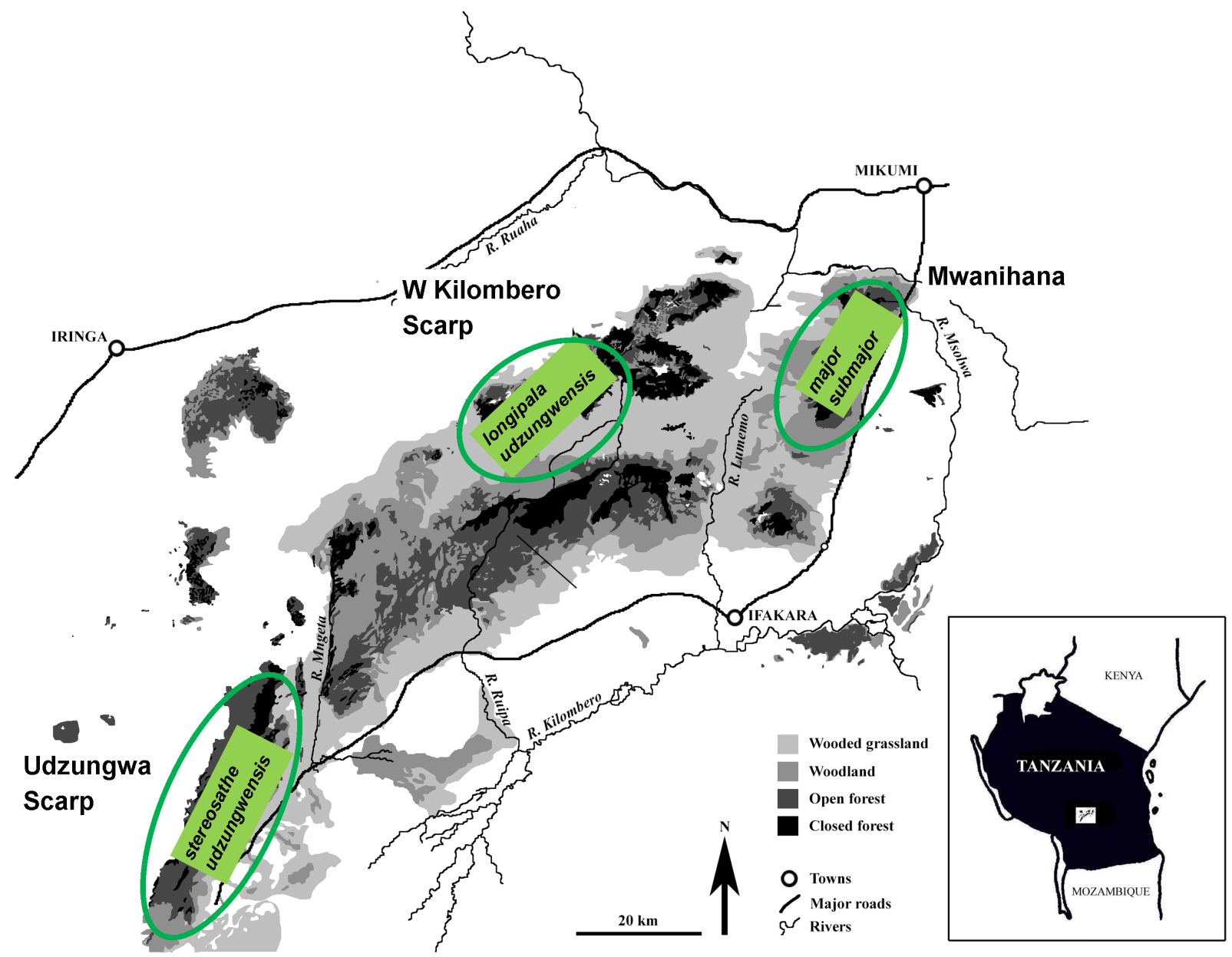

Fig. 13. Map of the Udzungwa Mts showing the forest reserves where Aquattuor species have been found, and the epithets of the species found. Based on Marshall et al. (2010: fig. 1). 


\section{References}

Akkari N. \& Enghoff H. 2011. On some surface structures of potential taxonomic importance in families of the suborders Polydesmidea and Dalodesmidea (Polydesmida, Diplopoda). Zookeys 156: 1-24. http:// dx.doi.org/10.3897/zookeys.156.2134

Attems C. 1909. Myriopoda. Wissenschaftliche Ergebnisse der schwedischen zoologischen Expedition nach dem Kilimandjaro, dem Meru und den umgebenden Massaisteppen Deutsch-Ostafrikas 1905-1906 3 (19): 1-64.

Burgess N., Butinsky T.M., Cordeiro N.J., Doggart N.H., Fjeldså J., Howell K.M., Kilahama F.B., Loader S.P., Lovett J.C., Mbilinyi B., Menegon M., Moyer D.C., Nashanda E., Perkin A., Rovero F., Stanley W.T. \& Stuart S.N. 2007. The biological importance of the Eastern Arc Mountains of Tanzania and Kenya. Biological Conservation 134: 209-231. http://dx.doi.org/10.1016/j.biocon.2006.08.015

EnghoffH. 2014. A mountain of millipedes I: An endemic species-group of the genus Chaleponcus Attems, 1914, from the Udzungwa Mountains, Tanzania (Diplopoda, Spirostreptida, Odontopygidae). European Journal of Taxonomy 100: 1-75. http://dx.doi.org/10.5852/ejt.2014.100

Frederiksen S.B. 2013a. East African odontopygid millipedes 2: A new, geographically disjunct species of Chaleponcus (Attems 1914) from the Pare Mts, Tanzania (Diplopoda, Spirostreptida, Odontopygidae). Zootaxa 3636: 597-600. http://dx.doi.org/10.11646/zootaxa.3636.4.7

Frederiksen S.B. 2013b. East African odontopygid millipedes 3: Two new genera; Lamelloramus and Aquattuor proposed to contain three new species (Diplopoda, Spirostreptida, Odontopygidae). Zootaxa 3694: 59-66. http://dx.doi.org/10.11646/zootaxa.3694.1.4

Frederiksen S.B. \& Enghoff H. 2012. East African odontopygid millipedes 1: Five new species of Xystopyge (Attems, 1909) and a proposal for a new gonopod terminology (Diplopoda; Spirostreptida; Odontopygidae). Zootaxa 3485: 69-82.

Frederiksen S.B. \& Enghoff H. 2015. East African odontopygid millipedes 4: A restricted redefinition of the genus Rhamphidarpoides Kraus, 1960, a related new genus, five new species, and notes on solenomere function (Diplopoda; Spirostreptida; Odontopygidae). Zootaxa 3926: 541-560. http:// dx.doi.org/10.11646/zootaxa.3926.4.5

Kraus O. 1960. Äthiopische Diplopoden I. Monographie der Odontopygidae-Odontopyginae (Diplopoda, Spirostreptoidea). Annalen van het Koninklijk Museum van Belgisch-Congo 82: 1-207.

Kraus O. 1966. Phylogenie, Chorologie und Systematik der Odontopygoideen (Diplopoda, Spirostreptomorpha). Abhandlungen der Senckenbergischen naturforschenden Gesellschaft 512: 1-143.

Marshall A.R., Jørgensbye H.I.O., Rovero F., Platts P.L., White P.C.L. \& Lovett J.C. 2010. The speciesarea relationship and confounding variables in a threatened monkey community. American Journal of Primatology 72: 325-336. http://dx.doi.org/10.1002/ajp.20787

Nonnotte P., Guillou H., Le Gall B., Benoit M., Cotten J. \& Scaillet S. 2008. New K-Ar age determinations of Kilimanjaro volcano in the North Tanzanian diverging rift, East Africa. Journal of Volcanology and Geothermal Research 173 (1-2): 99-112. http://dx.doi.org/10.1016/j.jvolgeores.2007.12.042

Reboleira A.S.P.S. \& Enghoff H. 2015. Redescription of Lusitanipus alternans (Verhoeff, 1893) (Diplopoda, Callipoda, Dorypetalidae) and ecological data on its Laboulbeniales ectoparasites in caves. Zootaxa 3957: 567-576. http://dx.doi.org/10.11646/zootaxa.3957.5.5 
Soini E. 2005. Changing livelihoods on the slopes of Mt. Kilimanjaro, Tanzania: Challenges and opportunities in the Chagga homegarden system. Agroforestry Systems 64: 157-167. http://dx.doi. org/10.1007/s10457-004-1023-y

Manuscript received: 20 August 2015

Manuscript accepted: 8 October 2015

Published on: 6 November 2015

Topic editor: Rudy Jocqué

Desk editor: Danny Eibye-Jacobsen

Printed versions of all papers are also deposited in the libraries of the institutes that are members of the EJT consortium: Muséum National d'Histoire Naturelle, Paris, France; Botanic Garden Meise, Belgium; Royal Museum for Central Africa, Tervuren, Belgium; Natural History Museum, London, United Kingdom; Royal Belgian Institute of Natural Sciences, Brussels, Belgium; Natural History Museum of Denmark, Copenhagen, Denmark. 